\title{
Trace Metals Content Of The Sewage From The Sewer Network Of Abidjan (Côte d'Ivoire)
}

\section{Gnagne Agnes Essoh Jean Eudes Yves}

Laboratoire des Sciences de l'Environnement (LSE), Unité de Formation et de Recherches en Sciences et Gestion de l'Environnement (UFR-SGE),

Université Nangui Abrogoua, Abidjan, Côte d'Ivoire

\section{Yapo Ossey Bernard}

Laboratoire des Sciences de l'Environnement (LSE), Unité de Formation et de Recherches en Sciences et Gestion de l'Environnement (UFR-SGE),

Université Nangui Abrogoua, Abidjan, Côte d'Ivoire

Laboratoire Central de l'Environnement du Centre Ivoirien Anti-pollution

(LCE-CIAPOL), Abidjan, Côte d'Ivoire

\section{Ohou-Yao Marie Jeanne}

Unité de Formation et de Recherche en Environnement, UniversitéJean

Lorougnon Guédéde Daloa, Daloa, Côte d’Ivoire

\section{Ladji Meite \\ Ballet Tiama Guy Nicaise Mambo Veronique}

Laboratoire des Sciences de l'Environnement (LSE), Unité de Formation et de Recherches en Sciences et Gestion de l'Environnement (UFR-SGE),

Université Nangui Abrogoua, Abidjan, Côte d'Ivoire

doi: 10.19044/esj.2016.v12n11p412 URL:http://dx.doi.org/10.19044/esj.2016.v12n11p412

\begin{abstract}
Many studies have incriminated the effluents of the sewer network of Abidjan as major trace metal contamination sources in the Ebrié Lagoon. However, no data are available on wastewater regarding trace metal contaminations in Cote d'Ivoire. Thus, this study aimed at assessing the level of contamination of wastewater by metals copper, iron, cadmium, lead and Zinc. To achieve this objective, six campaigns were carried out from december 2013 to november 2014 in eight specific sites. The samples were analyzed using an atomic absorption spectrophotometer AA20 Varian, after mineralization. The results showed a significant contamination of effluents from the sewer network. The order of metals concentrations was Fe $>\mathrm{Zn}>$ $\mathrm{Cu}>\mathrm{Pb}>\mathrm{Cd}$. Total metal concentrations $(\mu \mathrm{g} / \mathrm{L})$ ranged from 313.4 to 881.5 for Fe, 144 to 240 for $\mathrm{Zn}, 132$ to 318 for $\mathrm{Cu}, 10$ to 30 for $\mathrm{Cd}$ and 114.3 to
\end{abstract}


263 for $\mathrm{Pb}$. Among these values only $\mathrm{Cd}$ concentrations considerably exceeded WHO guideline value $(10 \mu \mathrm{g} / \mathrm{L})$.

Keywords: Trace metals, wastewater, sewer network, pollution, Abidjan (Côte d'Ivoire)

\section{Introduction}

Trace metals occur in the environment naturally or through human activities. Potential sources include natural aging of the earth's crust, mining, soil erosion, industrial discharges, urban runoff, sewage effluent. The prolonged presence of these contaminants in urban environment and its proximity to the population can significantly amplify their exposure to metals by inhalation, ingestion and dermal contact (Mielke and Reagan, 1998; Boyd et al., 1999; Mielke et al., 1999). Contamination by heavy metals of different environmental compartments, particularly aquatic ecosystems, has been extensively studied because of their resistance to biodegradation, their toxicity and tendency to the phenomena of bioaccumulation and biomagnification along food chains (Callender and Rice, 2000; Morin et al., 2008; Liang et al., 2011; Lenoble et al., 2013). The increase of total concentrations of metals in ecosystems is becoming increasingly worrying in the light of population growth, concomitant expansion of urbanization, industrialization and agriculture in recent decades (Zourarah, 2009; Jayaprakash, 2010). Among these substances, copper (Cu), zinc $(\mathrm{Zn})$, cadmium $(\mathrm{Cd})$, Iron $(\mathrm{Fe})$ and Lead $(\mathrm{Pb})$ have been the subject of several studies in the field of environmental pollution because of their use in many areas of human activities (Tang et al., 2010 ; Oyeyiola et al., 2013). In Cote d'Ivoire, several studies have focused on the determination of the trace metals concentrations in water, sediment and aquatic species in the estuarine part of the Ebrié lagoon (Kone et al., 2008; Affian et al., 2009; Yao et al., 2009; Coulibaly et al., 2012, Bakary and Yao, 2015). Most of these studies have pointed the wastewater from the sewer system of the city of Abidjan as a major potential source of metal pollution of the Ebrié lagoon. In fact, the Ebrié lagoon remains the receptacle of urban and industrial effluent discharges, of runoff and domestic solid waste of the city, containing relatively large amounts of metals. However, to our knowledge, no study has focused on the metal charge of sewage. Thus, the objective of this study is to assess the level of the metals $\mathrm{Cu}, \mathrm{Zn}, \mathrm{Cd}, \mathrm{Pb}$ and $\mathrm{Fe}$ in the wastewater of the sewer network of Abidjan which is discharged in the Ebrié lagoon. 


\section{Materials and Methods}

\section{Sewage network of Abidjan}

The sewage network is $1158 \mathrm{~km}$ long. This network comprises one main collector and many secondary collectors. The main collector, with a length of $25 \mathrm{~km}$, connects Abobo town in the north to Port-bouet town on the seafront (Figure 1). On the main collector, Three (03) sampling points have been selected. In addition, five (05) sampling points have been selected on the secondary collectors (Table I). In this study, six wastewater sampling campaigns were conducted between december 2013 and november 2014. The wastewater samples were collected at each station. A volume of $500 \mathrm{~mL}$ was collected in polyethylene bottles and immediately acidified with $0.5 \mathrm{ml}$ of nitric acid (65\%). These samples were kept in an icebox at $4^{\circ} \mathrm{C}$ and then transported to the laboratory according to the procedures outlined by AFNOR (2001) and Rodier et al., (2009).

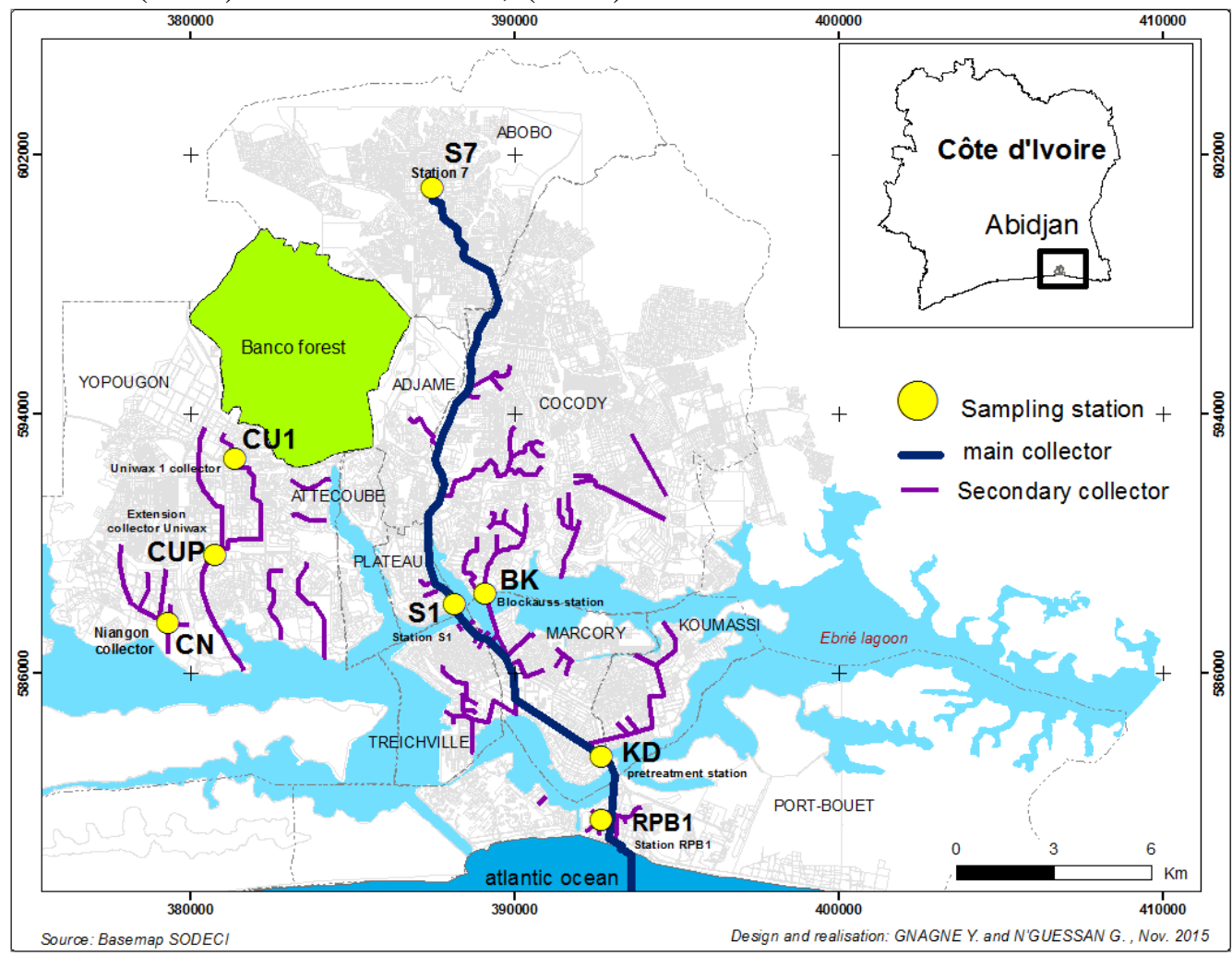

Figure 1: Location of collectors and sampling stations 
Table I: Identification and localization of samples on different points of the sewer system

\begin{tabular}{|c|c|c|}
\hline Stations & Positions & $\begin{array}{c}\text { geographic } \\
\text { Coordinates(UTM) }\end{array}$ \\
\hline S7 Station & $\begin{array}{l}\text { At the head of the main collector of sewer network, at Abobo } \\
\text { township }\end{array}$ & $\begin{array}{l}-\mathrm{X}: 388241 \\
-\mathrm{Y}: 599508\end{array}$ \\
\hline S1 Station & Located on the main network, at Plateau township & $\begin{array}{l}-\mathrm{X}: 388028 \\
-\mathrm{Y}: 587975\end{array}$ \\
\hline $\begin{array}{l}\text { Pretreatment } \\
\text { Station (KD) }\end{array}$ & $\begin{array}{l}\text { Last station on the main collector before discharging effluent } \\
\text { into the Atlantic Ocean. It is the outflow of wastewater from } \\
\text { the main collector and the secondary collectors from all } \\
\text { townships except those of Yopougon, Riviera and Port- } \\
\text { Bouet. It is located in the townships of Koumassi. }\end{array}$ & $\begin{array}{l}-\mathrm{X}: 393011 \\
-\mathrm{Y}: 583331\end{array}$ \\
\hline RBP1Station & $\begin{array}{l}\text { It represents the outflow of wastewater from secondary } \\
\text { collectors in the township of Port-Bouet. }\end{array}$ & $\begin{array}{l}-\mathrm{X}: 392869 \\
-\mathrm{Y}: 581535\end{array}$ \\
\hline $\begin{array}{l}\text { Blockosso } \\
\text { Station (BK) }\end{array}$ & $\begin{array}{c}\text { It collects and conveys some of the wastewater of the } \\
\text { township of Cocody in the main collector via 7J1 station in } \\
\text { Treichville. }\end{array}$ & $\begin{array}{l}-\mathrm{X}: 389441 \\
-\mathrm{Y}: 588536\end{array}$ \\
\hline $\mathrm{CN}$ & Township of Yopougon, sector of Niangon & $\begin{array}{l}-\mathrm{X}: 378605 \\
-\mathrm{Y}: 587499\end{array}$ \\
\hline CU1 & $\begin{array}{l}\text { One of the manholes in the upper part of the Uniwax } \\
\text { collector. This manhole is located in the area of the textile } \\
\text { company Uniwax. }\end{array}$ & $\begin{array}{l}-\mathrm{X}: 380687 \\
-\mathrm{Y}: 592839\end{array}$ \\
\hline CUP & $\begin{array}{l}\text { Townships of Yopougon, extension of the Uniwax Collector } \\
\text { to Yahosehi }\end{array}$ & $\begin{array}{l}-\mathrm{X}: 380545 \\
-\mathrm{Y}: 589653\end{array}$ \\
\hline
\end{tabular}

CN: Niangon collector, CU1: Uniwax collector, CUP : Extension Uniwax collector

UTM :Universal Transverse Mercator

\section{Sample processing and analysis}

Wastewater from the sewer network being highly loaded with organic matter, a mineralization step was necessary prior to analysis, in order to limit interference related to organic matter. The method of mineralization is described by ISO 5961 (1994) standard. It consists of introducing $100 \mathrm{~mL}$ of each homogenized sample in a $250 \mathrm{ml}$ beaker. To this $100 \mathrm{~mL}$ sample, $1 \mathrm{~mL}$ of nitric acid (65\%) and $1 \mathrm{~mL}$ of hydrogen peroxide (32\%) were added. This mixture was heated on a hot plate and evaporated up to about $0.5 \mathrm{~mL}$. It is essential that the sample is not completely evaporated. The residue $(0.5 \mathrm{~mL})$ is dissolved in $1 \mathrm{~mL}$ of nitric acid (65\%) and $5 \mathrm{~mL}$ of ultrapure water. This mixture is transferred to a $100 \mathrm{ml}$ flask and completed to a volume of 100 $\mathrm{mL}$ with ultrapure water. Then, this solution is filtered using a filter of $0.45 \mu \mathrm{m}$ diameter. Finally, the filtrate is used for the determination of the concentrations of trace metals by means of an atomic absorption spectrophotometer AA20 Varian. The detection limits of trace metals were $0.0005 \mathrm{mg} / \mathrm{L}$ for copper, iron, Zinc; $0.0003 \mathrm{mg} / \mathrm{L}$ for lead and $0.0001 \mathrm{mg} / \mathrm{L}$ for cadmium.

\section{Statistical processing of the data}

The collected data were processed using the Statistica 7.1software (Statsoft, 2005). Initially the mean, standard deviation and coefficient of 
variation of trace metals were determined for each sampling station. Secondly, a Principal Component Analysis (PCA) was used to study and classify the effluents from the sewage network according to their metal compositions.

\section{Results and discussion}

Order of abundance of the metals in the wastewater over all sampling campaigns

Figure 2 shows the total concentrations of each metal on all six (06) sampling campaigns. It indicates the presence of $\mathrm{Cd}, \mathrm{Cu}, \mathrm{Fe}, \mathrm{Pb}$ and $\mathrm{Zn}$ in the effluents of the sewer network of Abidjan. It reveals also that concentrations of Fe are the highest of all metals, and that those of $\mathrm{Cd}$ are the lowest. The order of metals concentrations is $\mathrm{Fe}>\mathrm{Zn}>\mathrm{Cu}>\mathrm{Pb}>\mathrm{Cd}$. This order is not much different from that found by Bakary and Yao (2015) in open collectors of Abidjan. These authors found the following order: Fe $>\mathrm{Zn}$ $>\mathrm{Cu}>\mathrm{Cr}>\mathrm{Cd}>\mathrm{Pb}$. According to them, the total concentrations of $\mathrm{Pb}$ in effluent were lower than the detection limit. They postulated that the $\mathrm{Pb}$ has been retained by adsorption or by flocculation and deposited along the path of the effluents.

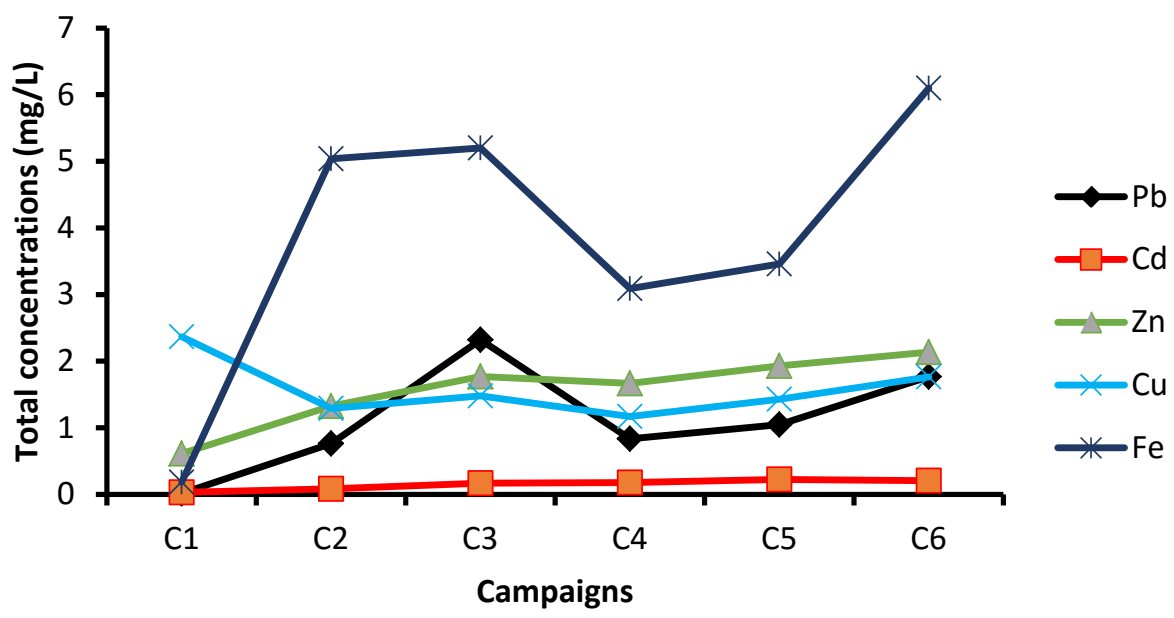

C1: Campaign 1; C2: Campaign 2; C3: Campaign 3; C4: Campaign 4; C5: Campaign 5; C6: Campaign 6

Figure 2: Total concentrations of trace metals over all sampling campaigns

\section{Trace metal concentrations range along the sewer network}

The evolution of trace metal concentrations in the wastewater from one site to another of the sewer network is presented in Table II. Total metal concentrations $(\mu \mathrm{g} / \mathrm{L})$ ranged from 313.4 to 881.5 for Fe, 144 to 240 for Zn, 132 to 318 for $\mathrm{Cu}, 10$ to 30 for $\mathrm{Cd}$ and114.3 to 263 for $\mathrm{Pb}$. In addition, the 
coefficient of variation of metal concentrations is between $47.5 \%$ and $141.2 \%$. This indicates that there is a high dispersion of concentrations from one campaign to another in the different stations studied. This dispersion can be due to a punctual and intermittent mechanism of sewage contamination by metals.

Table II: Concentrations of trace metals at different sampling stations

\begin{tabular}{|c|c|c|c|c|c|c|}
\hline Stations & & $\mathrm{Pb}(\mu \mathrm{g} / \mathrm{L})$ & Cd $(\mu \mathrm{g} / \mathrm{L})$ & $\mathrm{Zn}(\mu \mathrm{g} / \mathrm{L})$ & $\mathrm{Cu}(\mu \mathrm{g} / \mathrm{L})$ & Fe $(\mu \mathrm{g} / \mathrm{L})$ \\
\hline S7 & $\begin{array}{l}\text { Moy } \pm \sigma \\
\text { CV (\%) }\end{array}$ & $\begin{array}{c}164,1 \pm 171,8 \\
104,7\end{array}$ & $\begin{array}{c}11,8 \pm 11,2 \\
94,9\end{array}$ & $\begin{array}{c}178 \pm 91,6 \\
51,4\end{array}$ & $\begin{array}{c}156,6 \pm 79,6 \\
50,8\end{array}$ & $\begin{array}{c}590,3 \pm 513,4 \\
86,9\end{array}$ \\
\hline RPB1 & $\begin{array}{c}\text { Moy } \pm \sigma \\
\text { CV(\%) }\end{array}$ & $\begin{array}{c}150,6 \pm 153,4 \\
102\end{array}$ & $\begin{array}{c}10 \pm 8 \\
80\end{array}$ & $\begin{array}{c}180,5 \pm 94,6 \\
52,4\end{array}$ & $\begin{array}{c}132 \pm 97 \\
73,5\end{array}$ & $\begin{array}{c}361,5 \pm 275,4 \\
76,2\end{array}$ \\
\hline BK & $\begin{array}{l}\text { Moy } \pm \sigma \\
\text { CV }(\%)\end{array}$ & $\begin{array}{c}153,2 \pm 164 \\
107\end{array}$ & $\begin{array}{c}11,1 \pm 7,5 \\
67,6\end{array}$ & $\begin{array}{c}144 \pm 98,4 \\
68,3\end{array}$ & $\begin{array}{c}150,6 \pm 109,4 \\
72,6\end{array}$ & $\begin{array}{c}315 \pm 243,6 \\
77,3\end{array}$ \\
\hline $\mathrm{KD}$ & $\begin{array}{c}\text { Moy } \pm \sigma \\
\text { CV(\%) }\end{array}$ & $\begin{array}{c}263 \pm 286 \\
108,7\end{array}$ & $\begin{array}{c}16,2 \pm 7,5 \\
47,5\end{array}$ & $\begin{array}{c}145 \pm 88,6 \\
61,1 \\
\end{array}$ & $\begin{array}{c}144,3 \pm 106,2 \\
73,6\end{array}$ & $\begin{array}{c}412,3 \pm 345,1 \\
83,7 \\
\end{array}$ \\
\hline S1 & $\begin{array}{c}\text { Moy } \pm \sigma \\
\text { CV }(\%)\end{array}$ & $\begin{array}{c}141 \pm 137,3 \\
97,4\end{array}$ & $\begin{array}{c}13,5 \pm 11 \\
81,5\end{array}$ & $\begin{array}{c}197 \pm 168 \\
82,2\end{array}$ & $\begin{array}{c}153,8 \pm 74 \\
48,1\end{array}$ & $\begin{array}{c}377 \pm 308,8 \\
95,6\end{array}$ \\
\hline CU1 & $\begin{array}{c}\text { Moy } \pm \sigma \\
\text { CV(\%) }\end{array}$ & $\begin{array}{c}114,3 \pm 161,4 \\
141,2\end{array}$ & $\begin{array}{c}30 \pm 25,4 \\
84,7\end{array}$ & $\begin{array}{c}240 \pm 239,8 \\
99,9\end{array}$ & $\begin{array}{c}318 \pm 220 \\
69,8\end{array}$ & $\begin{array}{c}881,5 \pm 843,5 \\
54\end{array}$ \\
\hline CUP & $\begin{array}{c}\operatorname{Moy} \pm \sigma \\
\operatorname{CV}(\%)\end{array}$ & $\begin{array}{c}172,3 \pm 205,4 \\
119,2\end{array}$ & $\begin{array}{c}16,6 \pm 12,5 \\
75,3\end{array}$ & $\begin{array}{c}190 \pm 127 \\
66,8\end{array}$ & $\begin{array}{c}178,5 \pm 102,5 \\
57,4\end{array}$ & $\begin{array}{c}407,8 \pm 220,1 \\
185,3\end{array}$ \\
\hline $\mathrm{CN}$ & $\begin{array}{c}\operatorname{Moy} \pm \sigma \\
\text { CV(\%) }\end{array}$ & $\begin{array}{c}160,1 \pm 0,182 \\
113,7\end{array}$ & $\begin{array}{c}11,3 \pm 13,2 \\
116,8\end{array}$ & $\begin{array}{c}167,6 \pm 111,5 \\
66,5\end{array}$ & $\begin{array}{c}154 \pm 81,6 \\
53\end{array}$ & $\begin{array}{c}313,4 \pm 278,6 \\
88,9\end{array}$ \\
\hline
\end{tabular}

\section{Metal concentrations in liquid effluents and standard values}

Metal concentrations in wastewater of different localities, national wastewater discharge standards and WHO guideline values are shown in Table III. According to this table, Zn concentrations of the effluents of the sewer network of Abidjan are similar to those obtained by Nassali et al. (2001) and Aboueloufa et al. (2002) in urban discharges of Morocco. These concentrations are low than the WHO guideline value. The $\mathrm{Pb}$ concentrations do not exceed the WHO guideline and the Ivorian standard for wastewater discharge. These concentrations are close to those found by Abdoulaye et al. (2013) in the effluents of the WWTP of SEBKA in Mauritania. The concentrations of $\mathrm{Cu}$ and $\mathrm{Fe}$ found in the wastewater of the sewer network of Abidjan comply with the national standards for wastewater discharge, set respectively at 500 and $5000 \mu \mathrm{g} / \mathrm{L}$. On the other side, the concentrations of $\mathrm{Cu}$ are much higher than those found in other studies on wastewater discharges (Nassali et al., 2001; Fouad et al., 2014; Bakary and Yao 2015). As for $\mathrm{Fe}$, the concentrations are in the same order as those found by Aboueloufa et al. (2002). Cd concentrations considerably exceeded the limit value $(10 \mu \mathrm{g} / \mathrm{L})$ recommended by WHO, (2012) in the context of environmental protection (Table III). These values are close to those found by Nassali et al. (2001) and Fouad et al. (2014) in urban wastewater and sewer discharges in Morocco. The comparison of the average concentrations 
of metals in the sewage of the two types of collector of Abidjan indicates that the concentrations of $\mathrm{Cd}, \mathrm{Zn}$, and Fe measured in open collectors discharges are lower than those found in sewage network discharges. The higher levels of these metals in the wastewater from the open collectors were probably due to the composition of this wastewater. Indeed, this wastewater comprises runoff and domestic sewage. These collectors are the receptacle of trash of all sorts. Unlike $\mathrm{Cd}, \mathrm{Zn}$, and $\mathrm{Fe}$, the concentrations of $\mathrm{Cu}$ and $\mathrm{Pb}$ are lower in open collectors discharges compared to the sewer network discharges. In fact, the sewage effluent is the result of domestic and industrial effluents. High concentrations of $\mathrm{Cu}$ could originate from domestic effluents and dyes used in the textile industry. According to Davis (1975), domestic discharges are responsible for a third of the charges (1/3) of copper in wastewater treatment facilities in the US. For lead, they could come from paint waste. The wastewater from the sewer system is a source of water contamination by metals in the lagoon. According to Bakary and Yao (2015), the metal concentrations in the water of the bay of Cocody are $42 \mu \mathrm{g} / \mathrm{L}$ for Cd, $94 \mu \mathrm{g} / \mathrm{L}$ for $\mathrm{Zn}, 85 \mu \mathrm{g} / \mathrm{L}$ for $\mathrm{Cu}, 27 \mu \mathrm{g} / \mathrm{L}$ for pb and $51 \mu \mathrm{g} / \mathrm{L}$ for Fe. The presence of metals in wastewater in this study urges preventive measures because the discharges are continuous in the aquatic environment. Therefore it may pose a risk to the health of aquatic life and humans. According to Kone et al. (2008) and Coulibaly et al. (2012), some fish (Sarotherodon melanotheron) and some gastropods (Tympanotonus fuscatus fuscatus and Tympanotonus fuscatus radula) are contaminated by metal.

Table III: Concentrations ( $\mu \mathrm{g} / \mathrm{L}$ )of $\mathrm{Cd}, \mathrm{Zn}, \mathrm{Fe}, \mathrm{Cu}$, and $\mathrm{Pb}$ in sewageand standard values

\begin{tabular}{|c|c|c|c|c|c|c|}
\hline Sites or Standards & $\mathrm{Cd}$ & $\mathrm{Zn}$ & $\mathrm{Cu}$ & $\mathrm{Pb}$ & $\mathrm{Fe}$ & REFERENCES \\
\hline $\begin{array}{l}\text { Abidjan (SW) } \\
\text { Côte d'Ivoire }\end{array}$ & $10-30$ & $144-240$ & $132-318$ & $114.3-263$ & $313.4-881.5$ & Present study \\
\hline $\begin{array}{l}\text { Abidjan (UW) Côte } \\
\text { d'Ivoire }\end{array}$ & 47 & 319 & 93 & $<\mathrm{DL}$ & 1600 & $\begin{array}{c}\text { Bakary and Yao } \\
(2015)\end{array}$ \\
\hline $\begin{array}{c}\text { Casablanca (UW) } \\
\text { Moroco- } \\
\end{array}$ & $22-23$ & $39-54$ & $14-22$ & $<\mathrm{DL}$ & 123 & $\begin{array}{c}\text { Fouad et al. } \\
(2014)\end{array}$ \\
\hline $\begin{array}{c}\text { Algeria (UW) } \\
\text { Algeria (IW) }\end{array}$ & $\begin{array}{c}3-500 \\
4-3200\end{array}$ & $\begin{array}{c}80-1600 \\
10-700\end{array}$ & $\begin{array}{l}- \\
-\end{array}$ & $\begin{array}{c}20-60 \\
03-500\end{array}$ & - & $\begin{array}{c}\text { Sadia and Ahmed } \\
\text { (2013) }\end{array}$ \\
\hline $\begin{array}{l}\text { Mauritanie } \\
\text { (WWTP) }\end{array}$ & - & - & - & $104.5-176.5$ & - & $\begin{array}{c}\text { Abdoulaye et al. } \\
\text { (2013) }\end{array}$ \\
\hline $\begin{array}{l}\text { Oudja (UW) } \\
\text { Moroco }\end{array}$ & - & 220 & - & - & 950 & $\begin{array}{l}\text { Abouelouafa et } \\
\text { al. (2002) }\end{array}$ \\
\hline $\begin{array}{l}\text { Kenitra (SW) } \\
\text { Moroco- }\end{array}$ & 10.8 & 498 & 40 & 32 & 2800 & $\begin{array}{l}\text { Nassali et al. } \\
\text { (2001) }\end{array}$ \\
\hline Kenitra (IW) Moroco- & 3.8 & 186 & 45 & 28 & 3000 & \\
\hline $\begin{array}{c}\text { Bay in Ebrie Lagoon } \\
\text { Cocody } \\
\text { Côte d'Ivoire }\end{array}$ & 42 & 94 & 85 & 27 & 51 & $\begin{array}{c}\text { Bakary and Yao } \\
\text { (2015) }\end{array}$ \\
\hline $\begin{array}{l}\text { Ivorian wastewater } \\
\text { discharge standards }\end{array}$ & - & - & 500 & 500 & 5000 & MINEEF (2008) \\
\hline WHO guideline value & 10 & 2000 & 200 & 5000 & 5000 & WHO(2012) \\
\hline
\end{tabular}

SW: Sewer Wastewater, UW: Urban wastewater; IW: Industrial Wastewater 


\section{Types of sewage according to trace metals}

The Principal Component Analysis (PCA) was based on five (05) metals descriptors ( $\mathrm{Pb}, \mathrm{Zn}, \mathrm{Cu}, \mathrm{Cd}, \mathrm{Fe}$ ) as well as eight (08) sampling points (S7, RPB1, BK, KD, S1, CU1, CUP, CN). The factorial analysis (F1-F2) indicates $93.81 \%$ of the expressed variance (Figure 3). The factor 1(F1) alone explains $75.66 \%$ of the expressed variance. It is perfectly correlated with $\mathrm{Fe}, \mathrm{Cu}, \mathrm{Cd}, \mathrm{Zn}$ (Table IV). According to table V, these variables are best linked to each other ( $\mathrm{Cd}$ and $\mathrm{Cu}$ (0.953), $\mathrm{Cu}$ and $\mathrm{Fe}$ (0.891), $\mathrm{Cd}$ and $\mathrm{Fe}$ (0.857), $\mathrm{Zn}$ and $\mathrm{Cu}(0.811), \mathrm{Zn}$ and Fe (0.765) and $\mathrm{Cd}$ and $\mathrm{Zn}(0.740)$ ). In addition, the strongest correlations between $\mathrm{Fe}, \mathrm{Cu}$ and $\mathrm{Cd}$ could indicate that these metals come from the same origin. Thus, from the right to the left, the factor 1 (F1) expresses an increasing gradient of contamination of wastewater in $\mathrm{Fe}, \mathrm{Cu}, \mathrm{Cd}, \mathrm{Zn}$. In contrast, the factor (F2) exhibits18.15\% of the variance expressed. It is significantly correlated with $\mathrm{Pb}$. From bottom to top, this factor 2 (F2) indicates an increasing gradient of contamination by $\mathrm{Pb}$.

Table IV: Factorial coordinates of variables

\begin{tabular}{ccc} 
& \multicolumn{3}{c}{ Factors } \\
\cline { 2 - 3 } & $\mathrm{F} 1$ & $\mathrm{~F} 2$ \\
\hline Variables & $-0,971^{*}$ & 0,135 \\
\hline $\mathrm{Cu}$ & $-0,916^{*}$ & $-0,234$ \\
\hline $\mathrm{Zn}$ & $-0,916^{*}$ & 0,227 \\
\hline $\mathrm{Fe}$ & $0,906^{*}$ & 0,375 \\
\hline $\mathrm{Cd}$ & 0,581 & $0,8^{*}$ \\
\hline $\mathrm{Pb}$ & $*$ Good correlation
\end{tabular}

Table V: Pearson correlation matrix of metal variables

\begin{tabular}{cccccc}
\hline & $\mathbf{P b}$ & $\mathbf{C d}$ & $\mathbf{Z n}$ & $\mathbf{C u}$ & $\mathbf{F e}$ \\
$\mathbf{P b}$ & 1 & & & & \\
$\mathbf{C d}$ & $-0,231$ & 1 & & & \\
$\mathbf{Z n}$ & $\mathbf{- 0 , 6 7 5}$ & $\mathbf{0 , 7 4 0}$ & 1 & & \\
$\mathbf{C u}$ & $-0,479$ & $\mathbf{0 , 9 5 3}$ & $\mathbf{0 , 8 1 1}$ & 1 & \\
$\mathbf{F e}$ & $-0,355$ & $\mathbf{0 , 8 5 7}$ & $\mathbf{0 , 7 6 5}$ & $\mathbf{0 , 8 9 1}$ & 1 \\
\hline
\end{tabular}

The values in red and bold are significantly different from 0 at a level of alpha $=0.05$ significance

These data let to interpret the graph of samples with three (03) major classes of stations which are clearly shown on the main plan (F1 - F2) (Figure 3).

Class 1 contains only the effluents at the start of the Uniwax Collector (CU1). These effluents are rich in $\mathrm{Fe}, \mathrm{Cu}, \mathrm{Cd}$ and $\mathrm{Zn}$. Indeed, this collector drains the wastewater from the textile industry Uniwax. So, the presence of high concentrations of these metals in the effluents of this station 
can be explained by the use of dyes and various chemicals by the textile manufacturing process. Some synthetic dyes such as metal complex dyes contain one or more metal elements in their molecular structure. These include $\mathrm{Cu}$ and Fe (Mansour, 2010). Also, according to Rauch and Pacyna (2009) dyes contain Cd.

Class 2 represents the effluents from CUP, BK, S1, KD, CN, S7 and RPB1 stations. These effluents are poor in trace metals. This could be due to a high proportion of domestic sewage at these stations. Indeed, according to Gnagne et al. (2015), these effluents have a high domestic character. However, the concentrations of metals encountered in these effluents could come from the corrosion of water mains and the use of metals in domestic activities and household products as suggested by Abdoulaye et al.(2013). The low concentrations of these effluents could be also related to the fixation of the metals to the solid fraction of the wastewater.

Class 3 corresponds to effluents from the pretreatment station (KD). These effluents are rich in $\mathrm{Pb}$. This can be linked to the accumulation phenomenon. In fact, this station receives all effluents of the main collector before discharge into the receiving environment. Moreover, this station could receive industrial effluents rich in lead which may come from paint industries located in the industrial area of Koumassi.

Variables distribution

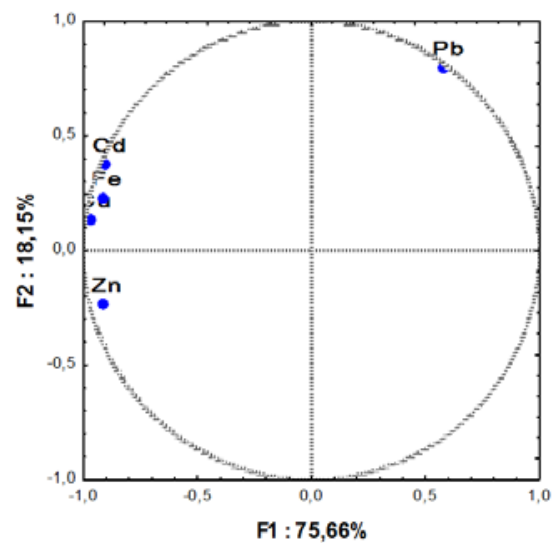

Sampling distribution

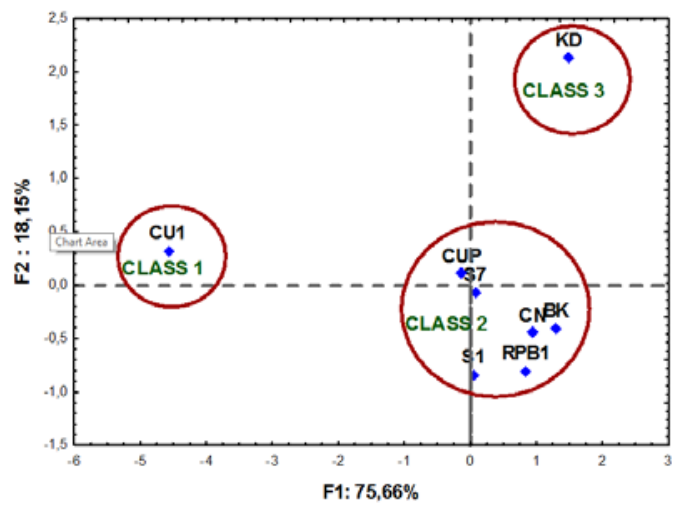

Figure 3: PCA score plot for Factor 1 and Factor 2 for metal contaminants measured in wastewater of sewer network of Abidjan.

\section{Conclusion}

This work shows the presence of the trace metals $\mathrm{Fe}, \mathrm{Zn}, \mathrm{Cu}, \mathrm{Pb}$, and Cdinthe wastewater drained by the sewer network of Abidjan. Total metal concentrations $(\mu \mathrm{g} / \mathrm{L}$ ) ranged from 313.4 to 881.5 for Fe, 144 to 240 for Zn, 132 to 318 for $\mathrm{Cu}, 10$ to 30 for $\mathrm{Cd}$ and 114.3 to 263 for $\mathrm{Pb}$. Among the five 
metals studied, Cd concentrations considerably exceeded the WHO guideline value $(10 \mu \mathrm{g} / \mathrm{L})$. On the other side, the order of metal concentrations is

$\mathrm{Fe}>\mathrm{Zn}>\mathrm{Cu}>\mathrm{Pb}>\mathrm{Cd}$. This study shows clearly that metallic pollution is due to a punctual and intermittent mechanism because the variation coefficient of metal concentrations varies between $47.5 \%$ and $141.3 \%$.Thus, given the large volumes of wastewater discharged into the receiving water regularly, measures must be taken to prevent environmental disasters. Increased investigations should be conducted for the removal of metal from the wastewater from the sewer system. This treated water instead of being discharged into the lagoon and / or the sea could be reused in agriculture or in industries, as practiced in the countries of northern Africa. This is important in the need to ensure that future generations have access to safe drinking water and a healthy environment.

\section{Acknowledgments}

The authors express their infinite gratitude to the Association of African Universities (AAU) for their financial support to the implementation of this study. They also thank the society in charge of water distribution in Côte d'Ivoire (SODECI) and the Laboratory of Synthesis of Industrial Processes, Environment and New Energies (LAPISEN) for their collaboration throughout the study. We are also grateful to $\mathrm{Mr}$ Gbocho Thierry.

\section{References:}

Abdoulaye D N., Mohamed O. S’.A.,Ould K., and Khalid I. N. . Contribution à l'étude de l'origine du plomb contenu dans les effluents de la STEP utilises en agriculture dans le périmètre maraicher du Sebkha, Nouakchott, Mauritanie. Larhyss Journal, 2013.

Abouelouafa M, Hassan E. H., Kharboua M., et Berrichi A. Caractérisation physico-chimique et bactériologique des eaux usées brutes de la ville d’Oujda: canal principal et Oued Bounaïm, Maroc. Actes Inst. Agron.Vet, 2002.

Affian K., Robin M., Maanan M., Digbehi B., Djagoua E.V and Kouamé F. Heavy metal and polycyclic aromatic hydrocarbons in Ebriélagoonsediments, Côte d'Ivoire. Environmental Monitoring and Assessment, 2009.

AFNOR, Qualité de l'eau, Eléments majeurs - autres éléments et composés minéraux. Aubenas Ardèche, 6ed., 2001.

Bakary I and Yao K M. Physical and chemical parameters and trace metal concentrations in the Ebrie Lagoon (Côte d'Ivoire): influence of tides and urban wastewaters.J. Mater. Environ. Sci. 6 (5) 1321-1329, 2015. 
Boyd H.B., Pedersen F., Cohr K.H., Damborg A., Jakobsen B.M., Kristensen P. and Samsøe-Petersen L. Exposure scenarios and guidance values for urban soil pollutants. Regulatory Toxicology and Pharmacology, 1999.

Callender E. and Rice K.C. The urban environmental gradient: anthropogenic influences on the spatial and temporal distributions of lead and zinc in sediments. Environmental Science and Technology, 2000.

Coulibaly S., Atse B.C., Koffi K.M., Sylla S., Konan K.J. and Kouassi N.J. Seasonal accumulations of some heavy metal in water sediment and tissues of black-chinned tilapia Sarotherodon melanotheron from Bietri Bay in Ebrie Lagoon, Ivory Coast. Bulletin of Environmental Contamination and Toxicology, 2012.

Davis J.A., Jacknow J., Jour. Wat. Pollut. Contr. 47 (1975) 2292.

Fouad S., Hajjami K., Cohen N., et Chlaida M. Qualité physico-chimique et contamination métallique des eaux de l'Oued Hassar : impacts des eaux usées de la localité de Mediouna, Périurbain de Casablanca, Maroc. Afrique Science, 2014.

Gnagne A.Y., Yapo O. B., Meite L., Kouame V. K., Gadji A. A., Mambo V. et Houenou P. Caractérisation physico-chimique et bactériologique des eaux usées brutes du réseau d'égout de la ville d'Abidjan. Int. J. Biol. Chem. Sci, 2015.

ISO 5961. Qualité de l'eau : Dosage du cadmium par spectrométrie d'absorption atomique, Suisse, 1994.

Jayaprakash M., Urban B., Velmurugan P.M. et Srinivasalu S. Accumulation of total trace metals due to rapid urbanization in microtidal zone of Pallikaranai marsh, south of Chennai, India. Environmental Monitoring and Assessment, 170 (1-4), 2010.

Kone M., Dramane D., Karim T.S., Ardjouma D. and Houenou P.V. Comparison of trace element contamination levels $(\mathrm{Cu}, \mathrm{Zn}, \mathrm{Fe}, \mathrm{Cd}$ and $\mathrm{Pb}$ ) in the soft tissues of the gastropods Tympanotonus fuscatus fuscatus and Tympanotonus fuscatus radula collected in the Ebrie Lagoon (Côte d'Ivoire). Evidence of the risks linked to lead and cadmium. African Journal of Biotechnology, 2008.

Lenoble V., Omanović D., Garnier C., Mounier S., Đonlagić N., Le Poupon C. and Pižeta I. Distribution and chemical speciation of arsenic and heavy metals in highly contaminated waters used for health care purposes, Srebrenica, Bosnia and Herzegovina. Sci. Total Environ. 2013.

Liang C.P., Liu C.W., Jang C.S., Wang S.W. and Lee J.J. 2011. Assessing and managing the health risk due to ingestion of inorganic arsenic from fish and shellfish farmed in blackfoot disease areas for general Taiwanese. J. Hazard. Mater., 2011. 
Mansour H. B., Boughzala O., Barillier D., Dridi D., Chekir-Ghedira L. et Mosrati R. Les colorants textiles sources de contamination de l'eau : criblage de la toxicité et des méthodes de traitement. Journal of Water Science, 2010. Mielke H.W. and Reagan P.L. Soil is an important pathway of human lead exposure. Environmental Health Perspectives 106 (Suppl. 1), 1998.

Mielke H.W., Gonzales C.R., Smith M.K., and Mielke P.W. The urban environment and children's health: soils as an integrator of lead, zinc, and cadmium in New Orleans, Louisiana. U.S.A. Environmental Research Section A, 1999.

Ministère de l'Environnement, des Eaux et Forêts (MINEEF).Réglementation des Rejets et Emissions des Installations Classées pour la Protection de l'Environnement. Arrêté $\mathrm{n}^{\circ}$ 01164/MINEEF/CIAPOL/SDIIC du 4 novembre, 2008.

Morin S., Duong T.T., Dabrin A., Coynel A., Herlory O., Baudrimont M., Delmas F., Durrieu G., Schäfer J., Winterton P., Blanc G. a Coste, M. Longterm survey of heavy metal pollution, biofilm contamination and diatom community structure in the Riou Mort Waterhed, South-West France. Environmental Pollution, 151(3), 2008.

Nassali H., Ben Bouih H., Srhiri A., Hafiane A., and Dhahbi M. Impact des rejets sur la qualite metallique des eaux d'un lac naturel : merja fouarate a kenitra au maroc. Phys. Chem. News 3, 2001.

Oyeyiola A.O., Davidson C.M., Olayinka K.O., Oluseyi T.O et Alo B.I. Mulivariate analysis of potentially toxic metals in sediments of a tropical coastal lagoon. Environmental Monitoring and Assessment, 185(3), 2013.

Rauch J.N. and Pacyna J.M. Earth's global Ag, Al, Cr, Cu, Fe, Ni, Pb, and Zn cycles. Global Biogeochemical cycles, 2009.

Rodier J., Legube B., et Merlet N. L’analyse de l'eau : eaux naturelles, eaux résiduaires et eaux de mer. Edition: DUNOD, Paris, 9 ème édition, 2009.

Sadia R. et Ahmed K. Évaluation de la qualité physico-chimique et du niveau de contamination métallique $(\mathrm{Cd}, \mathrm{Pb}, \mathrm{Zn})$ des rejets d'eaux usées d'Oran et de Mostaganem (littoral Ouest algérien) Physio-Géo.Volume 7, 2013.

Statsoft. Statistica, Data analysis software system. Version 7.1. Tulsa, OK, USA, 2005.

Tang W., Shan B., Zhang H. and Mao Z. 2010. Heavy metal sources and associated risk in reponse to agricultural intensification in the estuarine sediments of Chaohu lake Valley, East China. Journal of Hazardous Materials, 2010.

WHO. Directives OMS pour l'utilisation sans risque des eaux usées, des excréta et des eaux ménagères. Volume II, utilisation des eaux usées en agriculture, 2012. 
Yao K.M., Métongo B.S., Trokourey A. andBokra Y. 2009. Assessment of Sediments Contamination by Heavy Metals in a Tropical Lagoon Urban Area, Ebrié Lagoon, Côte d'Ivoire. European Journal of Scientific Research,2009.

Zourarah B., Maanam M., Robin M., and Carruesco C. Sedimentary records of anthropogenic contribution to heavy metal contents in Oum Er Bia Estuary (Morocco). Environmental Chemistry Letters, 2009. 